\title{
Development of a Sustainability Index at the Local Level: methodological proposal and its application in the case study of Rio de Janeiro, Brazil
}

\author{
Ana Luiza Mendes Silva ${ }^{\mathrm{a}}$, Matheus Ferreira de Barros $^{\mathrm{a}}$ (D), Luan Santos ${ }^{\mathrm{b}, \mathrm{c} *}$ \\ aUniversidade Federal do Rio de Janeiro, Macaé, RJ, Brasil \\ bUniversidade Federal do Rio de Janeiro, Faculdade de Administração e Ciências Contábeis, Rio de Janeiro, RJ, Brasil \\ 'Universidade Federal do Rio de Janeiro, Programa de Engenharia de Produção, Rio de Janeiro, RJ, Brasil \\ *luan.santos@pep.ufrj.br
}

\begin{abstract}
Paper aims: This paper presents the methodological development of a sustainability indicator focused on the local level, based on the Municipal Human Development Index (MHDI).

Originality: The proposed indicator $(\mathrm{MHDl}+\mathrm{S})$ was built on the use of an indicator with simple methodology based on information provided by reliable Brazilian research institutes, making it easier to be updated and reproduced in other regions and states.
\end{abstract}

Research method: By adding the environmental factor to this well-known index, the proposed indicator $(\mathrm{MHDI}+\mathrm{S})$ is then applied to the state of Rio de Janeiro, Brazil, so that the municipalities have been categorized into different clusters.

Main findings: The results of this categorization were validated by statistical assessment (cluster analysis) showing that the groups have internal homogeneity and external heterogeneity.

Implications for theory and practice: The proposed indicator (MHDI+S) can assist public management at the local level, decentralizing the well-established federal perspective,

Keywords

Indicator. Sustainability. Municipal management, Cluster analysis.

How to cite this article: Silva, A. L. M., Barros, M. F., \& Santos, L. (2021). Development of a sustainability index at the local level: methodological proposal and its application in the case study of Rio de Janeiro, Brazil. Production, 31, e20210034. https://doi.org/10.1590/0103-6513.20210034.

Received: May 7, 2021; Accepted: Aug. 20, 2021.

\section{Introduction}

Discussions about environmental and human development agendas are not recent, although only in the beginning of the $21^{\text {st }}$ century more effective actions have been taken (Aracil et al., 2017; Santos \& Santos, 2021, 2012). Particularly in Brazil, since Rio 92, the country has taken a vital role in the sustainable development questions (Smith, 2013; Silva, 2012). Moreover, by hosting the Rio+20 conference in 2012, Brazil has reinforced this position, taking a prominent role in the international sustainability scenario, even though in the last few years the federal action has lost strength (Santos \& Santos, 2021). During this meeting, discussions over the new goals of development have begun, resulting in the launch of the Sustainable Development Goals (SDG) in 2015, composed of 17 main goals divided into 169 targets to be met until 2030. These new targets represent the main axe of development in the 2030 Agenda, taking into account a wide range of themes that can be summarized in four big main axes: environmental, social, economic and institutional (Santos \& Santos, 2017). 
Even though the Agenda 2030 focuses on the national level, strategies and actions must be developed in subnational and local levels. In this context, the municipal level can be considered as a main driver to reach these goals, because it is where there is a closer connection between the public power and the community (Rada et al., 2018; Rigamonti et al., 2016; Ghesla et al., 2018). Milani (2005) highlights that the conscient transformation of the local reality is the direct result of municipal development. Thus, it is clear the municipal administration role for the effective local transformation (Fuss et al., 2018). According to Buarque (1999), an efficient articulation between different actors of power is very important for local development. This articulation includes all spheres of power, from civil society and non-governmental organizations to private and political institutions, where each of them has their role and level of responsibility for the common objective (Ji et al., 2016; Cohen, 2011).

Therefore, the main motivation for this work is to provide environmental discussions to the practical field, and not just treat them as intangible objectives at the level of international conferences. As a consequence, this paper aims to present the methodological development of a sustainability indicator based on the Municipal Human Development Index (MHDI) (Winzer, 2016; Malik, 2014), in a way to add an environmental factor to this well-known index. The proposed indicator, called $\mathrm{MHDl}+\mathrm{S}$, is then applied to the state of Rio de Janeiro in order to understand the characteristics of the state's municipalities under the categories of the method. Also, the municipalities have been categorized in different clusters, taking into account their similarities to allow a precise comparison between them. So, it remains a research question that can be described as: How could the sustainability paradigm be inserted in the discussion of the Municipal Human Development Index?

In terms of structure, the paper is organized as follows: the introduction section (Section 1) is in charge of bringing the general motivation of the research, besides presenting its main objective and work structure. Section 2 analyses and discusses the theoretical context of the sustainable development indicators, especially looking at the local scale. Section 3 presents the methodological procedure of the work, in terms of definition of the proposed indicator, database analysis and treatment, definition and assessment of clusters, and validation of results. Section 4 discusses the main results of $\mathrm{MHDl}+\mathrm{S}$ in the state of Rio de Janeiro. Finally, Section 5 summarizes the main conclusions of the paper.

\section{Theoretical context and literature review}

This section presents and discusses indicators used in the sustainable development context, besides the local perspective for sustainability and the Municipal Human Development Index (MHDI).

\subsection{Sustainable development and its indicators}

The term "sustainable development" raised a paradigm that radically transformed 21 st century economics. Traditionally, the meaning of growth is associated with economic development, suggesting a notion of financial progress. On the other hand, it is important to dissociate "development" from "growth". Growth consists of measuring the production and income levels of a given group, that is, it addresses economic issues, while development systematically addresses raising the standard of living (Silva et al., 2009). Thus, the reach of sustainable development is conditioned to the conciliation between the concepts of development and growth, so that it is sensitive to social issues, environmental prudence and economic viability (Santos \& Santos, 2018). In this way, it is possible to affirm, according to Silva et al. (2009) that the concept of sustainability, although already widely used, is in constant construction and adaptation and corresponds to the most comprehensive definition of the development models proposed in modern times.

The use of instruments and tools for quantifying and analyzing information on the theme of sustainability is becoming increasingly important as support for research in the planning and development of a more sustainable society. In this way, the development of sustainability indicators has the capacity to signal problems before they become serious and cause irreversible damage to nature (Barbosa \& Cândido, 2009). Considering sustainable development as a complex phenomenon, the development of indicators must be guided by the approach of the most relevant aspects and that describe the reality considering its changing and dynamic aspects, in addition to considering future trends and perspectives (Martins \& Cândido, 2012; Rigamonti et al., 2016; Rada et al., 2018). Thus, the indicators act as providers of subsidies and information to assess the interactions between human and environmental systems.

For Schmidt et al. (1998), the reach of sustainability is based on the correct evaluation of actions, as from this analysis public policies and decision making are formulated. Thus, the adoption of indicators is more and more frequent in the most varied areas of human development (Rigamonti et al., 2016). Silva et al. (2009) also reinforces the differentiation of sustainability indicators in relation to the others by stating that they require 
an integrated worldview, that is, in which the economic, environmental and social dimensions are related in a community. Maragnon et al. (2004) apud Silva et al. (2009) highlights the relevance of a well-designed indicator, because in this way the indicator reveals problems before they evolve into a more serious situation, anticipating decision-making to resolve it.

\subsection{Sustainability in the local scale}

The theme of sustainable development is of such relevance in all global political spheres, which is one of the most debated topics in the United Nations sustainable agenda. According to the current UN Secretary-General, António Guterres, during a global conference on the theme held in Kyrgyzstan in 2017, public service is a critical component to achieve the SDG. It is necessary to explore new approaches, work differently, take risks and innovate (Ghesla et al., 2018; Rada et al., 2018). With this perspective, the focus on the municipal sphere is strategic, since it is the sphere with the lowest federal action, but with short-term results, making it easier to implement public measures for sustainable development (Schneider, 2009; Aracil et al., 2017; Wang et al., 2018).

The effectiveness of environmental policy depends, mainly, on raising awareness and involving the community with environmental issues (Fuss et al., 2018). In addition, for its proper implementation, it is necessary to provide financial, technical and human resources (Ji et al., 2016; Cohen, 2011; Rigamonti et al., 2016). Therefore, since the municipalities are the closest political sphere to the population, it is from them that this awareness must arise so that, from that, the other spheres can provide the necessary resources so that they can better manage all these issues associated with any and all types of pollution and environmental, social and/or economic degradation (Torres et al., 2010).

\subsection{The Municipal Human Development Index (MHDI)}

The MHDI was developed by the United Nations Development Programme (UNDP) in Brazil, the Brazilian Institute for Applied Economic Research (IPEA) and the João Pinheiro Foundation based on an adaptation of the global Human Development Index (HDI) for the Brazilian municipalities' reality (Lucena et al., 2018; Winzer, 2016; Malik, 2014). The index considers the same three original dimensions of the HDI - income, longevity and education - adapting the methodology to the Brazilian context and the availability of national data. Thus, according to the Human Development Atlas (Brasil, 2013), the main objectives of the development of a local human development indicator were summarized in:

a) Adjust the methodology to the Brazilian context, looking for more adequate indicators to assess the conditions of smaller social cores - the municipalities;

b) Adapt the methodology of the Global HDI to the indicators available in the Brazilian Demographic Censuses, in order to guarantee the same data source and comparability between all municipalities.

The MHDI calculation methodology works in a similar way to the global HDI taking into account the three main axes: income, longevity and education, identified as standard of living, long and healthy life and access to knowledge, respectively (Winzer, 2016; Malik, 2014). Nevertheless, this indicator fails to analyze environmental variables. It is exactly this weakness of the indicator methodology that motivates our proposal for the suggestion of a new indicator that considers the environmental aspect.

\section{Methods}

The research is based on the elaboration of the proposal for a unified indicator added to the Municipal Human Development Index (MHDI) for a more complete assessment of the situation of Brazilian municipalities. After this methodological procedure, the case study of the state of Rio de Janeiro was analyzed. In addition to the elaboration of this indicator, an analysis of the data is carried out to find out the common characteristics of the municipalities in order to group them in clusters, so that they can be compared. Following the classification proposed by Bairagi \& Munot (2019), this work can be described as a descriptive research with a quantitative approach. Table 1 describes a resume of the steps that the study was based on and its own description and main results.

The specific methodological steps are: definition of the indicator, database treatment, definition of clusters, analysis of clusters and validation of results. However, before starting describing this method, it is important to 
1. Methodological framework.

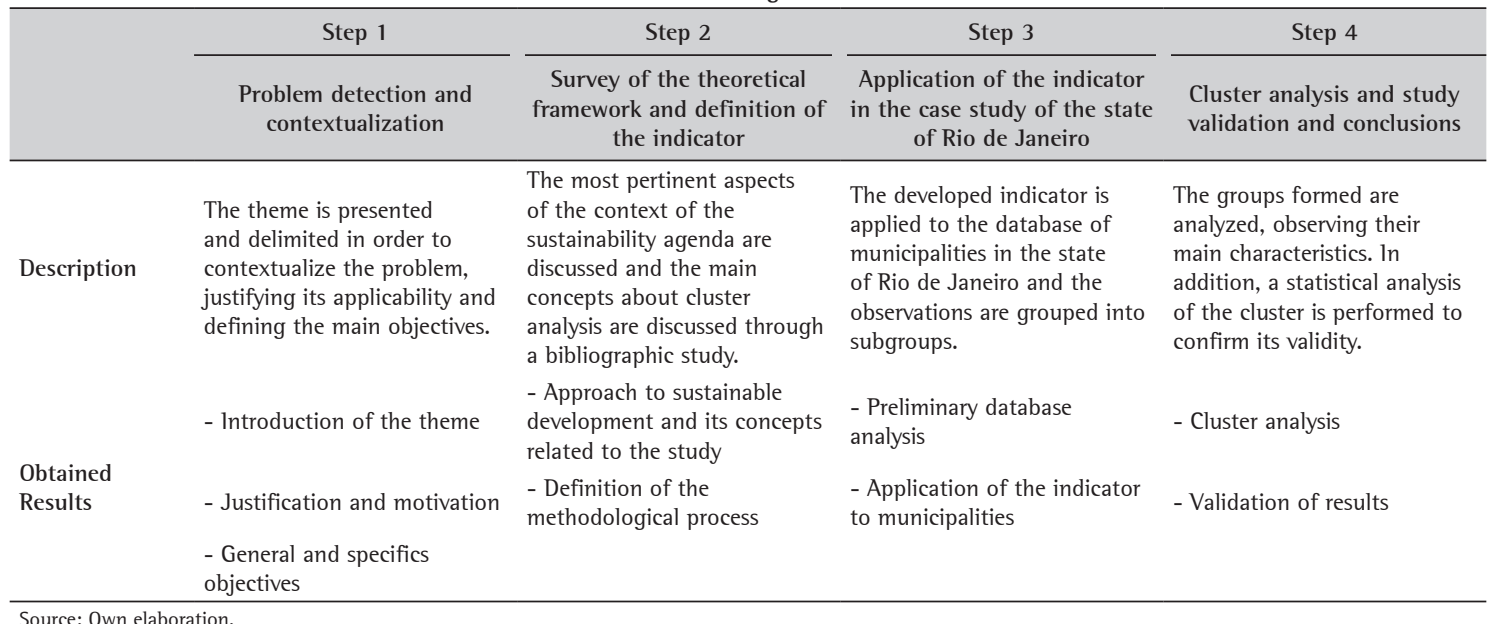

quickly look at the analysis of the existing indicators, in order to detect possible deficiencies, that is, possible aspects that are not observed and can be important in a more precise analysis. For this purpose, a bibliometric analysis is carried out and better detailed in the next subsection.

\subsection{Bibliometric analysis}

For a better understanding of the indicator in terms of methodology, a bibliographic search (bibliometry) was carried out in two main databases. Table 2 summarizes the results obtained from the search for keywords that may be contained in works similar to this study. The search was conducted on articles published in Brazil from 2015 in Scopus and Web of Science databases.

First, the keywords of group $[\mathrm{A}]$ for the method used were inserted, in this case the multivariate data analysis. Given the large number of publications found, a new research was carried out by applying a new filter referring to group [B] classified as the research context, that is, the environmental context. Then, to further restrict the results, another filter was added, referring to group [C] that characterizes the measure used, that is, the keywords linked to the index of sustainable development and public management.

It can be seen through the analysis of Table 2 that this research appears in few publications in Brazil, and, in this sense, the authors expect to contribute to the knowledge in this particular area and to stimulate other researches and studies that provide improvements for sustainable human development supported by technology.

\subsection{Indicator definition and database treatment}

The definition of the sustainable development indicator was based on an analysis of the already existing indexes that have methodological support and rigor in their development and use. In this way, the developed

Table 2. Bibliographic search.

\begin{tabular}{|c|c|c|c|}
\hline & Terms of search & Scopus & Web of Science \\
\hline Method $[A]$ & $\begin{array}{l}\text { [multivariate analysis OR multivariate data OR cluster analysis OR hierarchical cluster } \\
\text { analysis OR non-hierarchical cluster analysis] }\end{array}$ & 1.847 & 2.934 \\
\hline $\begin{array}{l}\text { Method }[\mathrm{A}] \\
+ \\
\text { Context }[\mathrm{B}]\end{array}$ & $\begin{array}{l}\text { [A] AND [sustainability OR environment OR sustainable development OR sustainable } \\
\text { environment OR triple bottom line] }\end{array}$ & 9 & 191 \\
\hline Method $[A]$ & & & \\
\hline $\begin{array}{l}+ \\
\text { Context }[\mathrm{B}] \\
+\end{array}$ & $\begin{array}{l}\text { [A] AND [B] AND [indicator OR index OR public management OR public policy OR } \\
\text { development index OR sustainability index] }\end{array}$ & 8 & 37 \\
\hline Measure $[\mathrm{C}]$ & & & \\
\hline
\end{tabular}

Source: Elaborated by the authors. 
indicator took place through an update of the Municipal Human Development Index (MHDI), since it is widely used worldwide, and its database is already consolidated by recognized research institutes like the Brazilian Institute of Applied Economics Research (IPEA) and the United Nations Development Program (UNDP).

As described in Section 2, it is known that the MHDI is calculated from a geometric average of three socioeconomic factors (education, longevity and income) and, therefore, the purpose of this study is to add the environmental factor in this calculation. Thus, the new MHDI will be called $\mathrm{MHDI}+\mathrm{S}$, where the three original factors will be considered in addition to the Environmental Index (EI).

The purpose of the study is to apply the MHDI+S on a local scale. For that purpose, it was considered the evaluation of municipalities in the state of Rio de Janeiro as a case study. The MHDI data are known and available by the Brazilian Institute of Geography and Statistics (IBGE, acronym in Portuguese), so the definition of the Environmental Index (El) is sufficient to define the $\mathrm{MHDI}+\mathrm{S}$ index. In the same direction as the definition of income, longevity and education indicators, it was defined that the El would be determined as the geometric mean of environmental aspects already known and quantified on the municipal scale. In this way, the El is conditioned to the availability of data on the environmental topics of interest.

Knowing that the availability of data at the municipal scale is scarce in Brazil, the municipal environmental data available in the Human Development Atlas for 2010, developed by the Institute for Applied Economic Research (IPEA, acronym in Portuguese) was analyzed in order to determine the El, resulting in three relevant factors: households with access to adequate sanitation (\%),households with access to garbage collection (\%) and households with access to piped water (\%). Thus, the El data was collected directly and resulted from a mean of the three before mentioned factors. Therefore, the $\mathrm{MHDl}+\mathrm{S}$ was defined as the geometric mean of the income, longevity, education and $\mathrm{El}$ indices and is described by Equation 1.

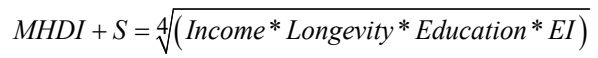

It is important to highlight that the income, longevity and education factors are already standardized and defined as an index from 0 to 1 and the same procedure was performed with the El. In the next section, the database will be detailed, showing the steps for collecting and processing it.

\subsection{Cluster analysis}

In specific studies, with a large number of observations and apparently heterogeneous objects, it is often desired to know the characteristics of this set, so that researchers resort to the segmentation of this large group into smaller sets (Hair Junior et al., 2009). In this case, one of the suitable methods is Cluster Analysis (CA).

CA also known as clustering is a multivariate analysis technique that studies the set of interdependent relationships between variables, differing from regression, because in this type of analysis there is no distinction between cause and effect variables. According to Fávero and Lopes (2017), cluster analysis is a statistical technique of interdependence that provides criteria for grouping objects that can be people, companies, products, courses, etc. from similarities, in such a way that the objects are homogeneous in their groups and the groups are heterogeneous among themselves. The purpose of the analysis is to use a "natural" structure created from objects, that is, the methodological basis of this method consists of the agglomeration of objects from a general group into smaller groups so that they have internal homogeneity (within the groups) and high external heterogeneity (between clusters) as a function of the observed variables.

As pointed out by Hair Junior et al. (2009), the concept of statistical variable must be carefully observed in CA. In this case, the statistical grouping variables determine the character of the objects, that is, they constitute characteristics that will be used to compare the objects. In CA, they are not estimated empirically, as in other multivariate techniques, but determined by the observer himself, and this makes this step critical in the analysis (Hair Junior et al., 2009).

The graph on the left on Figure 1 illustrates an ideal cluster classification, in which it is possible to separate them distinctly according to two arbitrary variables. It is noted that each observation fits into a grouping and that there is no intersection between them. On the other hand, in real situations, what happens is what is illustrated in the graph on the right on Figure 1, in which the boundaries of the clusters are not very well defined and the classification of the observations is not easily identified, since it can be categorized in different ways.

Everitt et al. (2001) apud Malhotra (2006) highlights the simplicity of the grouping method in the sense that it does not need great statistical rigor, basically consisting of an algorithm. 
Still according to Malhotra (2006), a grouping process can be done following a few steps, and Figure 2 illustrates a very useful methodology in this process. It starts with the formulation of the problem, that is, where the input variables will be defined. Then, the appropriate measure of distance between the observations is selected, which will determine the similarity between them. After this step, the most suitable agglomeration procedure is chosen. Finally, based on the outputs of the agglomerative procedure, the number of clusters is defined, followed finally by the interpretation of the profile of each group.

We can highlight that the steps are not independent. This means that there may be a need to go back to the previous step to correct or redo some consideration.
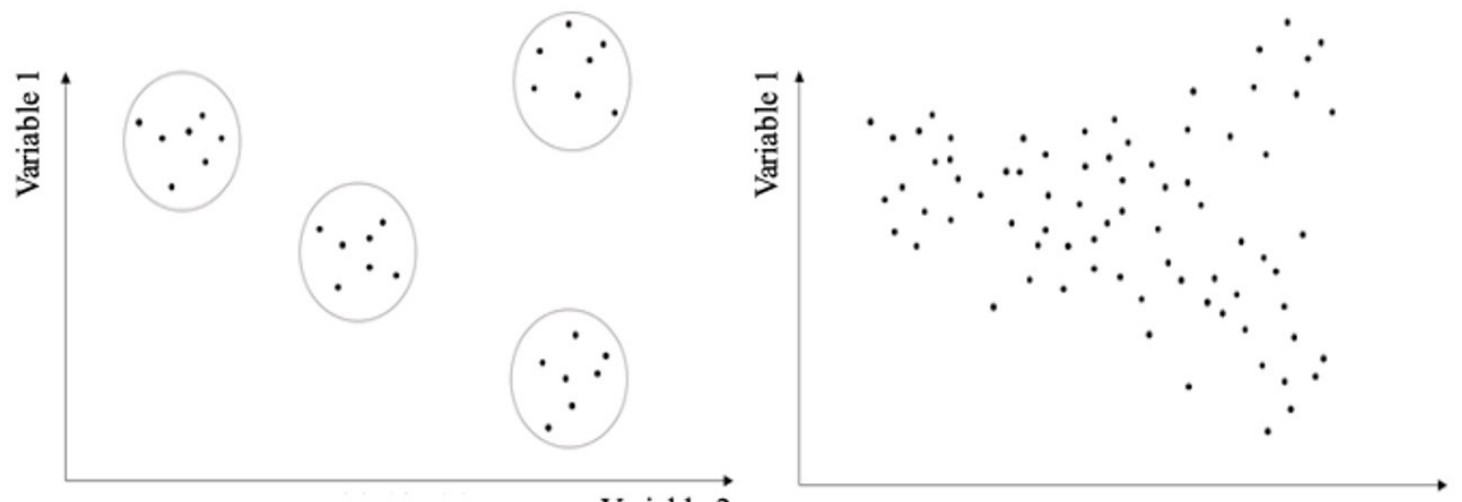

Variable 2

Variable 2

Figure 1. Ideal cluster situation and real cluster situation. Source: Adapted from Malhotra (2006).

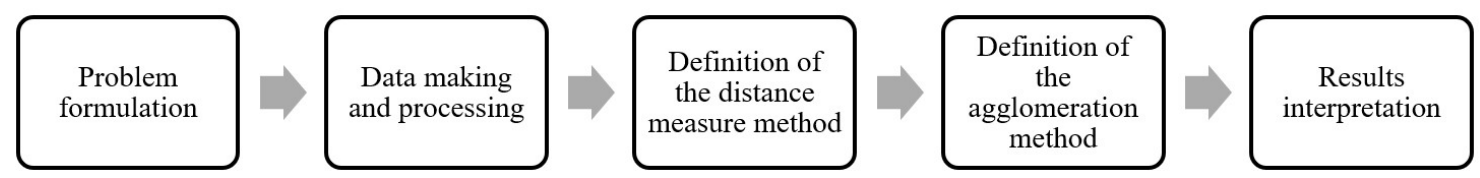

Figure 2. Steps of a cluster analysis. Source: Adapted from Malhotra (2006).

\section{Results and discussion}

This section analyzes and discusses the main results, focusing on its application, cluster analysis, and validation of results as the following subsections shows.

\subsection{Application}

Knowing that the objective of this study is to understand, evaluate and compare the socioenvironmental situation of the municipalities, a previous analysis of the database is necessary to discuss the existence of outlier data, as well as the existence of correlations between the variables, which can influence in the final analysis of the study. It is necessary that the data does not have outliers or correlations. Considering this statistical requirement, we could observe the existence of 6 municipalities located beyond the average dimensions: Macaé, Niterói, Rio de Janeiro, São Francisco de Itabapoana, São João da Barra and Sumidouro. These municipalities were excluded from the database for the subsequent analysis. This exclusion was made for a better interpretation of the data from a statistical point of view and it does not interfere of the validity of the analysis. From a practical point of view, even though they are important municipalities in the state scenario, for the purpose of this study - that is to create a method of analysis - the absence of these municipalities is not harmful, since our focus is on the development of the methodological process. It was also observed that there was no correlation between the variables observed. 
In addition to the detection of outliers, it is necessary to define the ideal agglomeration method and distance measurement, as they will be important in the elaboration of the observation groupings. This process took place with the combination of these two factors in the MINITAB software (version 17), as shown in Table 2. The combination results in an ideal number of clusters and a corresponding level of similarity. The choice of the ideal cluster number is made according to the researcher's interest and seeking the highest level of similarity possible. In the case of this study, the centroid link method with the Euclidean ${ }^{2}$ distance was chosen, resulting in 5 clusters with 95\% similarity between the observations, as shown in Table 3.

Table 3. Comparison between the connection method and distance measure combinations.

\begin{tabular}{|c|c|c|c|}
\hline Connection Method & Distance Measure & Number of Clusters & Similarity \\
\hline Mean & Euclidian & 4 & 73.748 \\
\hline Mean & Euclidian $^{2}$ & 4 & 92.373 \\
\hline Mean & Manhatan & 4 & 70.870 \\
\hline Centroid & Euclidian & 3 & 83.204 \\
\hline Centroid & Euclidian $^{2}$ & 5 & 95.489 \\
\hline Centroid & Manhatan & 3 & 81.400 \\
\hline Complete & Euclidian & 3 & 47.630 \\
\hline Complete & Euclidian $^{2}$ & 3 & 72.574 \\
\hline Complete & Manhatan & 3 & 33.714 \\
\hline Ward & Euclidian & 5 & 21.177 \\
\hline Ward & Euclidian $^{2}$ & 4 & 64.835 \\
\hline Ward & Manhatan & 6 & 21.091 \\
\hline
\end{tabular}

Source: Own elaboration.

\subsection{Cluster analysis}

The agglomeration of data resulted in five groups of municipalities. A summary per cluster can be seen in Table 4, with the number of cities per cluster $(\mathrm{N})$. In this table it is possible to observe the clusters geographically divided in the map of the State of Rio de Janeiro.

The range stipulated for the classification of each factor is equivalent to the one used by IBGE for the assessment of MHDI and it is shown in the synthesis table with the colors as detailed in Table 4:

Table 4. Average index per cluster and classification range.

\begin{tabular}{|c|c|c|c|c|c|c|c|c|}
\hline Cluster & $\mathrm{N}$ & Population & Income & Longevity & Education & El & $\mathrm{MHDI}+\mathrm{S}$ & MHDI \\
\hline 1 & 31 & $79,207.16$ & 0.709 & 0.817 & 0.634 & 0.753 & 0.725 & 0.716 \\
\hline 2 & 26 & $207,776.31$ & 0.706 & 0.818 & 0.648 & 0.868 & 0.755 & 0.721 \\
\hline 3 & 4 & $32,468.50$ & 0.692 & 0.813 & 0.595 & 0.509 & 0.641 & 0.694 \\
\hline 4 & 19 & $20,783.68$ & 0.674 & 0.806 & 0.558 & 0.676 & 0.672 & 0.671 \\
\hline 5 & 6 & $83,970.33$ & 0.739 & 0.833 & 0.659 & 0.595 & 0.700 & 0.740 \\
\hline \multirow[t]{2}{*}{ State } & 86 & $103,327.81$ & 0.702 & 0.816 & 0.621 & 0.748 & 0.717 & 0.708 \\
\hline & Range & Classification & & & & & & \\
\hline \multicolumn{2}{|c|}{$<0,550$} & Very low & & & & & & \\
\hline \multicolumn{2}{|c|}{$0,550-0,699$} & Medium & & & & & & \\
\hline \multicolumn{2}{|c|}{ 0,700-0,799 } & High & & & & & & \\
\hline \multicolumn{2}{|c|}{$>0,800$} & Very High & & & & & & \\
\hline
\end{tabular}

Source: Own elaboration based on Lucena et al. (2018), Winzer (2016), Malik (2014) and Instituto Brasileiro de Geografia e Estatística (2010).

In general, longevity can be observed, classified in all clusters as "Very High" for having values above 0.800. Geographically, with the observation of the map illustrated in Figure 3, it is possible to observe that the clusters are, in general, dispersed, that is, they are not clearly defined in the territory. Clusters 1,2 and 4 are the ones that have the greatest geographical proximity between the municipalities that compose them, and this is justified by the large amount of observations in each group compared to the other groups. 
Another relevant analysis to be done is related to the influence of the environmental factor (EI) on the MHDI of each cluster. Figure 4 shows the variation from the MHDI to the MHDl+S and shows that there is indeed a significant influence.

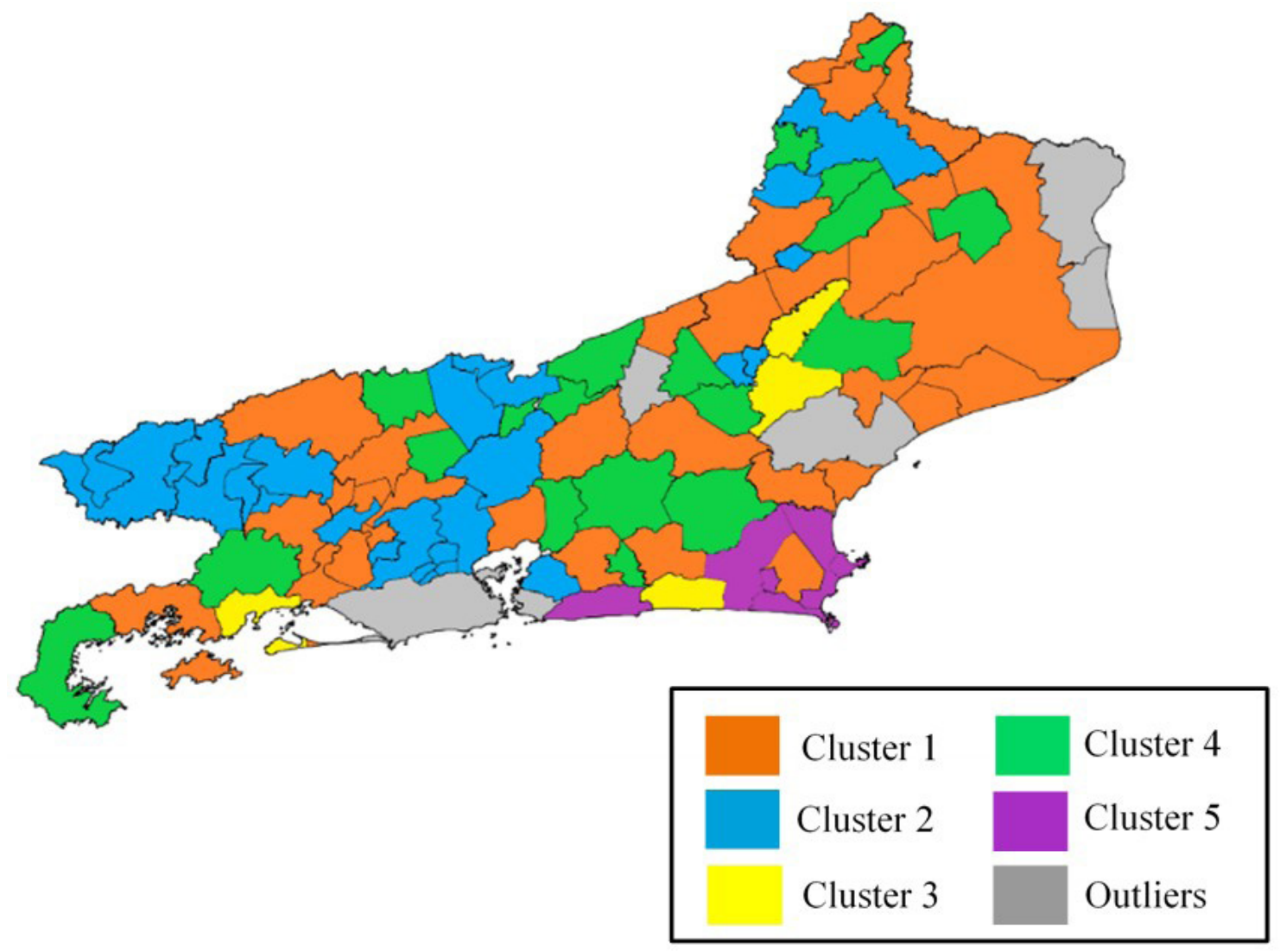

Figure 3. Map of the state of Rio de Janeiro divided into clusters. Source: Own elaboration.

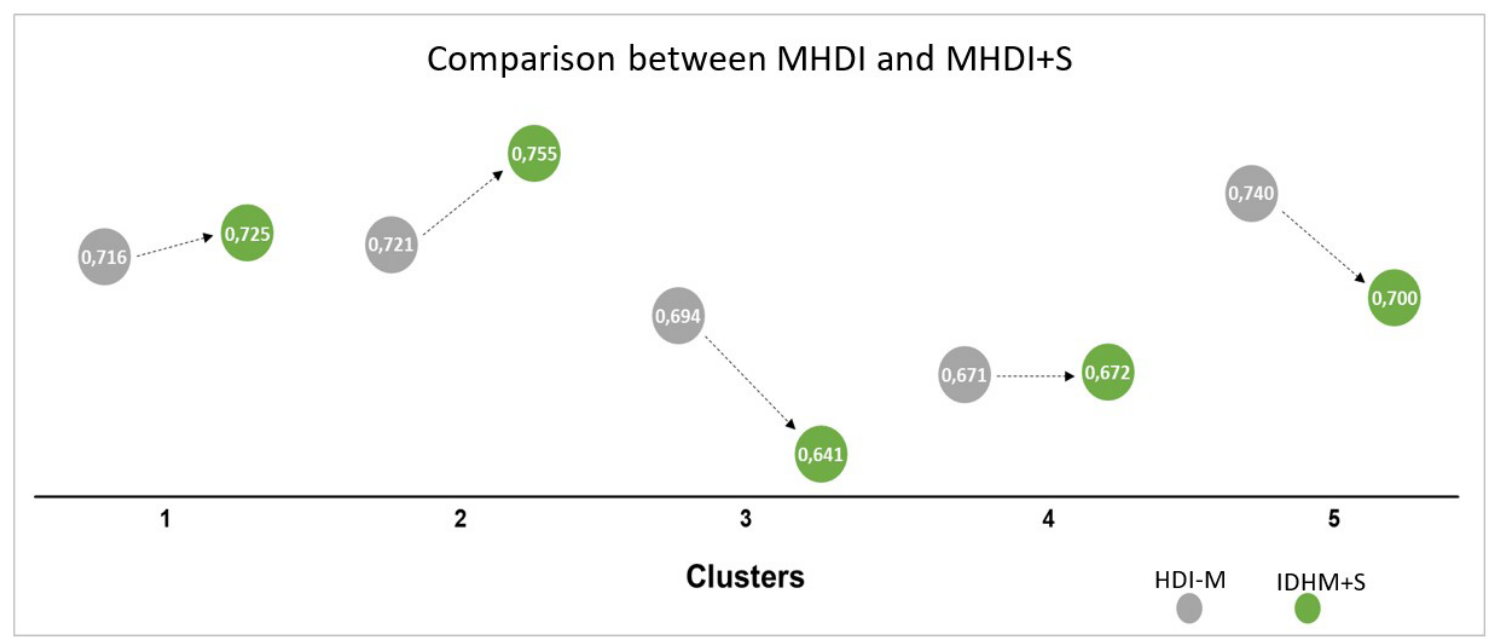

Figure 4. Variation from MHDl to $\mathrm{MHDl}+\mathrm{S}$ per cluster. Source: Own elaboration. 
Observing Table 4 of the synthesis of the results with the graph illustrated by the previous figure, it can be seen that groups 1 and 2 had a "High" and "Very High" El respectively, and, consequently, the MHDI+S increased in relation to HDI-M. In contrast, groups 3 and 5 had El "Very Low" and "Medium", respectively, resulting in a significant drop when comparing the MHDI with the MHDI. In the case of group 4, there was no significant change.

\subsection{Validation of results}

In the previous subsection, the results were exposed and their exploratory analysis were carried out, that is, the interpretation of the clusters in a more qualitative way, in which we sought to understand the characteristics of each group in relation to the $\mathrm{MHDl}+\mathrm{S}$ index and the variables that comprise it.

The following scheme illustrated by Figure 5 shows the necessary processes for determining the validity of the clusters. The first necessary test is the Normality Test as it is a basic test for the others. Then the Equality of Variance Test is carried out and finally the Equality of Means Test. The best scenarios are those in which the variances are equal, and the means are different, as it indicates homogeneity within the clusters and the heterogeneity between clusters.

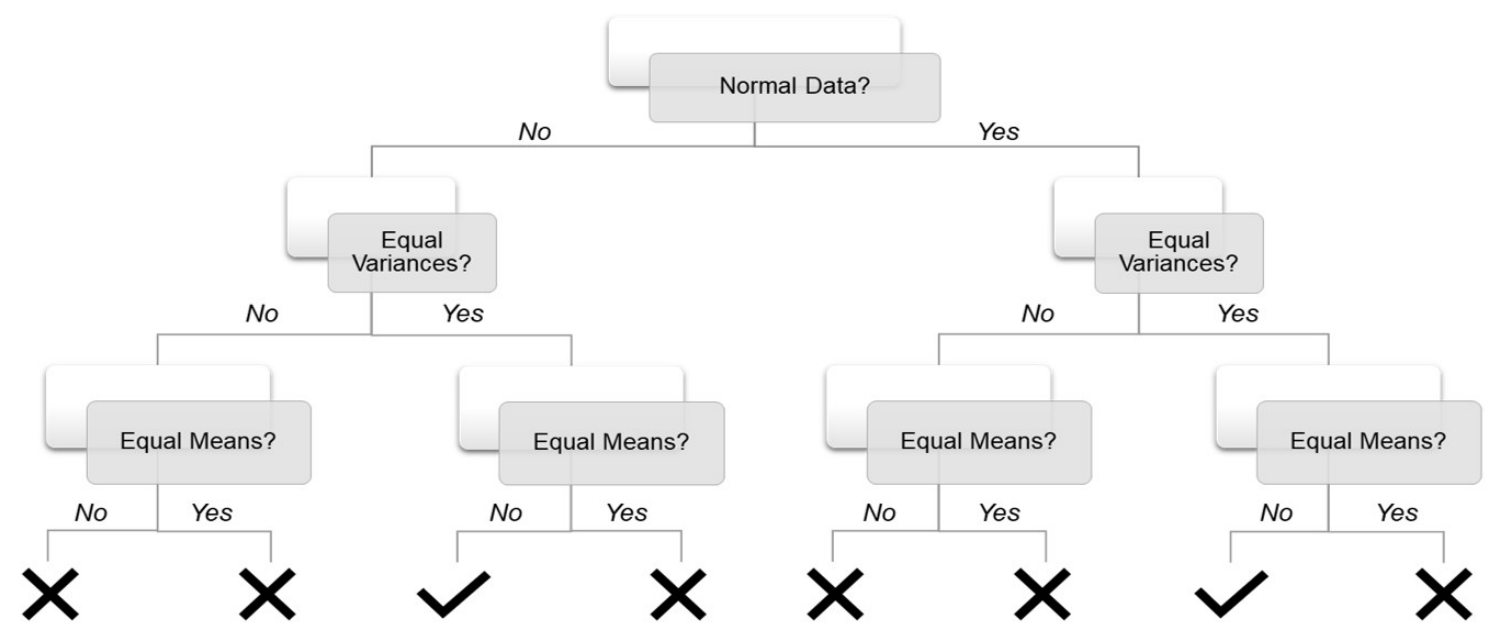

Figure 5. Cluster validation process. Source: Own elaboration.

In this study, tests were performed for each variable (income, longevity, education, El and MHDl+S) in the sample of 86 municipalities (excluding outliers) and Table 5 summarizes the results of the tests.

Discussions can be divided in a two-part assessment: 1 - the achievement of the objective of developing the sustainable development assessment index, useful for supporting public management and; 2 - the validity and reliability of the grouping of observations, where the groups created represent reality and facilitate the comparison of results between them.

In the first part, it can be concluded that the work achieved the proposed objective, since the index developed is easy to manipulate by managers, for it is based on information provided by reliable Brazilian research institutes and available at each demographic census. In addition, the way of calculating the $\mathrm{MHDI}+\mathrm{S}$ is easy to understand, and it can be updated as needed.

The second part of the discussion concerns the grouping of information. In this sense, it can be inferred that the groupings comfortably represent the reality regarding the $\mathrm{MHDl}+\mathrm{S}$. The statistical tests performed showed that the clusters have internal homogeneity, that is, they showed that the municipalities belonging to the same cluster have similar characteristics. In addition, they also showed that the clusters have external heterogeneity, that is, when comparing municipalities belonging to different clusters, it is concluded that they really have different characteristics in relation to the parameters used in the cluster. 
Table 5. Synthesis of statistical tests performed.

\begin{tabular}{|c|c|c|c|}
\hline & Normality Test (Kolmogorov-Smirnov) & $\begin{array}{c}\text { Equality of Variance Test (Bartlett/ } \\
\text { Levene) }\end{array}$ & $\begin{array}{l}\text { Equality of Means Test (ANOVA/ } \\
\text { Kruskal-Wallis) }\end{array}$ \\
\hline INCOME & P-value $=0.150 \rightarrow$ Normal Distribution & $\begin{array}{l}\text { Bartlett: } \mathrm{P} \text {-value }=0.338 \rightarrow \text { Equal } \\
\text { Variances }\end{array}$ & $\begin{array}{l}\text { ANOVA: P-value }=0.000 \rightarrow \text { At least } 1 \\
\text { pair of different means }\end{array}$ \\
\hline LONGEVITY & $\begin{array}{l}\text { P-value }=0.010 \rightarrow \text { Non-normal } \\
\text { Distribution }\end{array}$ & $\begin{array}{l}\text { Levene: } \mathrm{P} \text {-value }=0.757 \rightarrow \text { Equal } \\
\text { Variances }\end{array}$ & $\begin{array}{l}\text { Kruskal-Wallis: } \mathrm{P} \text {-value }=0.017 \rightarrow A t \\
\text { least } 1 \text { pair of different medians }\end{array}$ \\
\hline EDUCATION & P-value $=0.099 \rightarrow$ Normal Distribution & $\begin{array}{l}\text { Bartlett: } \mathrm{P} \text {-value }=0.219 \rightarrow \text { Equal } \\
\text { Variances }\end{array}$ & $\begin{array}{l}\text { ANOVA: } \text { P-value }=0.000 \rightarrow \text { At least } 1 \\
\text { pair of different means }\end{array}$ \\
\hline E1 & P-value $=0.150 \rightarrow$ Normal Distribution & $\begin{array}{l}\text { Bartlett: } \mathrm{P} \text {-value }=0.977 \rightarrow \text { Equal } \\
\text { Variances }\end{array}$ & $\begin{array}{l}\text { ANOVA: } \mathrm{P} \text {-value }=0.000 \rightarrow \text { At least } 1 \\
\text { pair of different means }\end{array}$ \\
\hline $\mathrm{IDHM}+\mathrm{S}$ & P-value $=0.150 \rightarrow$ Normal Distribution & $\begin{array}{l}\text { Bartlett: } \mathrm{P} \text {-value }=0.245 \rightarrow \text { Equal } \\
\text { Variances }\end{array}$ & $\begin{array}{l}\text { ANOVA: } P \text {-value }=0.000 \rightarrow \text { At least } 1 \\
\text { pair of different means }\end{array}$ \\
\hline
\end{tabular}

Source: Own elaboration.

\section{Conclusions}

Finally, human development needs will only be realized in effective public policies and practices if the problems become evident, that is, from the moment these problems are measurable in tangible data. At the municipal level, this context is even more relevant, given the importance and proximity of the State to the population. So, the logic of solving management problems linked to sustainable human development requires a correct diagnosis of the situation and an understanding of the heterogeneity of the observations, so that the measures are taken individually. The main contribution of this work is its usefulness for the public administration. Given that municipalities are the main actors in social and environmental changes, they need simple and effective tools to helo them making the best decisions. Furthermore, this work can be a control instrument at the state level, i.e., a way for governments to customize their investments and government actions according to the real needs of each region (cluster).

In order to continue this research and improve its results, it is important that the Environmental Index (El) is updated with more detailed information. A possible improvement of this index would be through the elaboration of a questionnaire to be applied to the environment departments of the municipalities of the state, since the other factors that integrate the $\mathrm{MHDI}+\mathrm{S}$ - Income, Longevity and Education - are already consolidated, reliable and widely used around the world. This questionnaire would be based on the 17 Sustainable Development Goals (SDGs) determined by the UN through the 2030 Agenda. In this way, the MHDl+S would be updated and in accord with the context of global sustainable development, promoting greater usability for the study.

\section{References}

Aracil, C., Haro, P., Giuntoli, J., \& Ollero, P. (2017). Proving the climate benefit in the production of biofuels from municipal solid waste refuse in Europe. Journal of Cleaner Production, 142, 2887-2900. http://dx.doi.org/10.1016/j.jclepro.2016.10.181.

Bairagi, V., \& Munot, M. V. (Eds.). (2019). Research methodology: a practical and scientific approach (320 p.). New York: Chapman and Hall/CRC Press. http://dx.doi.org/10.1201/9781351013277.

Barbosa, R. B., \& Cândido, G. A. (2009). Os índices de sustentabilidade municipal e as ações e políticas direcionadas para o desenvolvimento sustentável: um estudo exploratório em um município do brejo paraibano. In Anais do XXIX Encontro Nacional de Engenharia de Produção (ENEGEP). Local: editora.

Brasil. Atlas Brasil. (2013). Atlas do desenvolvimento humano no Brasil. Brasília: PNUD, IPEA, FJP.

Buarque, S. C. (1999). Metodologia de planejamento do desenvolvimento local e municipal sustentável: material para orientação técnica e treinamento de multiplicadores e técnicos em planejamento local e municipal. Brasília: IICA.

Cohen, M. P. (2011). Cities in times of crisis: the response of local governments in light of the global economic crisis: the role of the formation of human capital, urban innovation and strategic planning (Working Paper, No. 2011-01). Berkeley: Institute of Urban and Regional Development, University of California. Retrieved in 30 April 2020, from http://escholarship.org/uc/item/3432p4rb

Everitt, B. S., Landau, S., Leese, M., \& Stahl, D. (2001). Cluster analysis (4th ed.). Oxford: Oxford University Press.

Fávero, L. P., \& Lopes, B. P. (2017). Análise de dados: modelagem multivariada para tomadas de decisões. São Paulo: Elsevier.

Fuss, M., Vasconcelos Barros, R. T., \& Poganietz, W.-R. (2018). Designing a framework for municipal solid waste management towards sustainability in emerging economy countries: an application to a case study in Belo Horizonte (Brazil). Journal of Cleaner Production, 178, 655. http://dx.doi.org/10.1016/j.jclepro.2018.01.051.

Ghesla, P., Gomes, L., Caetano, M., Miranda, L., \& Dai-Prá, L. (2018). Municipal solid waste management from the experience of São Leopoldo/Brazil and Zurich/Switzerland. Sustainability, 10(10), 3716. http://dx.doi.org/10.3390/su10103716.

Hair Junior, J. F., Black, W. C., Babin, B. J., \& Anderson, R. (2009). Análise multivariada de dados (6. ed.). Porto Alegre: Bookman. 
Instituto Brasileiro de Geografia e Estatística - IBGE. (2010). Censo brasileiro de 2010. Rio de Janeiro. Retrieved in 2021, March 12, from https://censo2010.ibge.gov.br

Ji, H., Ahn, J., \& Chapman, J. (2016). The role of intergovernmental aid in defining fiscal sustainability at the sub-national level. Urban Studies, 53(14), 3063-3081. http://dx.doi.org/10.1177/0042098015601600. [Nov.]

Lucena, D. M. M., Figueiredo, F. W. S., Sousa, L. V. A., Paixa, L. S., Almeida, T. C. C., Galeo, S. J., Correa, J. A., Maciel, E. S., \& Adami, F. (2018). Correlation between municipal human development index and stroke mortality: a study of Brazilian capitals. BMC Research Notes, 11(1), 540. http://dx.doi.org/10.1186/s13104-018-3626-9. PMid:30068387.

Malhotra, N. K. (2006). Pesquisa de marketing: uma orientação aplicada (4. ed.). Porto Alegre: Bookman.

Malik, K. (2014). Human development report 2014: sustaining human progress: reducing vulnerabilities and building resilience. New York: United Nations Development Program.

Maragnon, M., Presznhuk, R., \& Sordi, R. (2004). Indicadores de sustentabilidade como instrumento para avaliação de comunidades em crise: aplicação à comunidade de Serra Negra, APA de Guaraqueçaba. In L. P. Peralta Agudelo (Ed.), Coletânea educação e tecnologia: indicadores de sustentabilidade. Curitiba: PPGTE/CEFET-PR.

Martins, M. F., \& Cândido, G. A. (2012). Índices de desenvolvimento sustentável para localidades: uma proposta metodológica de construção e análise. Revista de Gestão Social e Ambiental, 6(1), 3-19. http://dx.doi.org/10.24857/rgsa.v6i1.229.

Milani, C. (2005). Teorias do Capital Social e Desenvolvimento Local: lições a partir da experiência de Pintadas (Bahia, Brasil). In D. Santos, S. Cunha \& T. Guedes (Eds.), Capital social, participação política e desenvolvimento local: atores da sociedade civil e políticas de desenvolvimento local na Bahia. Salvador: Escola de Administração, Universidade Federal da Bahia.

Rada, E. C., Zatelli, C., Cioca, L. 1., \& Torretta, V. (2018). Selective collection quality index for municipal solid waste management. Sustainability, 10(1), 257. http://dx.doi.org/10.3390/su10010257.

Rigamonti, L., Sterpi, 1., \& Grosso, M. (2016). Integrated municipal waste management systems: an indicator to assess their environmental and economic sustainability. Ecological Indicators, 60,1-7. http://dx.doi.org/10.1016/j.ecolind.2015.06.022.

Santos, L., \& Santos, T. (2017). Os ODS e seus indicadores: novas classes gramaticais, uma mesma morfologia. Revista Pontes, 13(2), $13-17$.

Santos, T., \& Santos, L. (2012). Desarrollo sostenible y relaciones internacionales en el contexto de la Agenda 21. Trabajos de Investigación en Paradiplomacia, 2, 10-25.

Santos, T., \& Santos, L. (2018). Economia do meio ambiente e da energia: fundamentos teóricos e aplicações (1. ed.). Rio de Janeiro: Editora LTC.

Santos, T., \& Santos, L. (2021). Putting in check the Brazilian moves in the climate chessboard. Contexto Internacional, 43(1), 99-119. http://dx.doi.org/10.1590/s0102-8529.2019430100005.

Schmidt, W., Cazella, A. A., \& Turnes, V. A. (1998). Indicadores de sucesso de processos de desenvolvimento local (Trabalho apresentado em "Oficinas sobre indicadores de sucesso em programas de desenvolvimento local"). Brasília: PNUD.

Schneider, E. (2009). Gestão ambiental municipal: preservação ambiental e o desenvolvimento sustentável. Porto Alegre: UNIVATES.

Silva, E. F. (2012). Rio+20 and Brazil's policy on climate change. Nature Climate Change, 2(6), 379-380. http://dx.doi.org/10.1038/ nclimate 1525.

Silva, M. G., Cândido, G. A., \& Martins, M. F. (2009). Método de construção do índice de desenvolvimento local sustentável: uma proposta metodológica e aplicada. Revista Brasileira de Produtos Agroindustriais, 11(1), 55-72. http://dx.doi.org/10.15871/15178595/rbpa.v11n1p55-72.

Smith, R. J. (2013). A social worker's report from the United Nations Conference on Sustainable Development (Rio + 20). Social Work, 58(4), 369-372. http://dx.doi.org/10.1093/sw/swt032. PMid:24450024.

Torres, S. 1. C., Pardini, V. L., \& Ferreira, V. F. (2010). 0 que é sustentabilidade? Quimica Nova, 33(1), 58-67.

Wang, J., Maier, S., Horn, R., Holländer, R., \& Aschemann, R. (2018). Development of an ex-ante sustainability assessment methodology for municipal solid waste management innovations. Sustainability, 10(9), 3208. http://dx.doi.org/10.3390/su10093208.

Winzer, L. (2016). The relationship between the Municipal Human Development Index and rates of violent death in Brazilian Federal Units. Journal of Human Growth and Development, 26(2), 211-217. http://dx.doi.org/10.7322/jhgd.119275. 